\title{
In vitro resistance of Enterobacter cloacae isolated from fresh seafood to colistin
}

\author{
Marília Viana Albuquerque de Almeida[1], Izabelly Linhares Ponte Brito ${ }^{[2]}$, \\ Antonia Leonádia Siqueira de Carvalho ${ }^{[2]}$ and Renata Albuquerque Costa ${ }^{[1]}$
}

[1]. Programa de Mestrado em Biotecnologia, Centro Universitário INTA (UNINTA), Sobral, CE, Brasil.

[2]. Hospital Santa Casa de Misericórdia, Sobral, CE, Brasil.

\begin{abstract}
Introduction: Enterobacter cloacae is a clinically important bacterium from the Enterobacteriaceae family. This study evaluated resistance of E. cloacae strains from fish $(\mathrm{n}=14)$ and shrimp $(\mathrm{n}=9)$ to colistin. Methods: Biochemical identification and antimicrobial susceptibility tests were carried out in an automated Vitek ${ }^{2}$ instrument. Results: Colistin resistance was observed in $21.4 \%$ and $66.7 \%$ of the strains from fish and shrimp, respectively. We observed minimum inhibitory concentrations of $\geq 16$ $\mathrm{mg} / \mathrm{L}$ and $\leq 5 \mathrm{mg} / \mathrm{L}$ in 8 and 15 of all strains, respectively. Conclusions: Fish and shrimp can carry drug-resistant enterobacteria, which can be of clinical interest.
\end{abstract}

Keywords: Enterobacteriaceae. Vitek. Polymyxin.

Enterobacter cloacae, a member of the Enterobacteriaceae family, is a common bacterium that resides in the gut microbiota in healthy humans ${ }^{1}$. However, this species is also recognized as a major pathogen in nosocomial infections ${ }^{2}$, and is associated with food contamination ${ }^{3}$.

Recently, this pathogen has emerged as drug-resistant bacterial species; the development of antimicrobial resistance among Enterobacter spp., including resistance to extendedspectrum cephalosporins, is of great concern in both human and veterinary medicine ${ }^{4}$.

Therefore, isolation of E. cloacae strains that are resistant to colistin ${ }^{5}$, an antibiotic polypeptide still useful against multidrug-resistant gram-negative bacteria such as carbapenemresistant-Enterobacteriaceae ${ }^{6}$, is critical. However, some studies have shown that certain E. cloacae isolated from foods maybe resistant to this drug.

With the rise in infections due to multidrug-resistant gramnegative bacilli, more emphasis has been placed on colistin ${ }^{7}$. The present study aimed to evaluate resistance to colistin in $E$. cloacae strains isolated from food.

Enterobacter cloacae strains (23) isolated from fish Oreochromis niloticus $(\mathrm{n}=14)$ and shrimp Litopenaeus vannamei $(n=9)$ were used. Fresh seafood samples $(n=10)$ were purchased in the City of Sobral (Ceará State, Brazil). Skin and muscle of

Corresponding author: $\mathrm{Dr}^{\mathrm{a}}$ Renata Albuquerque Costa.

e-mail: renata.albuquerque@pq.cnpq.br

Received 21 February 2018

Accepted 8 May 2018 each fish $(50 \mathrm{~g})$ and whole shrimp samples $(50 \mathrm{~g})$ were inoculated in $450 \mathrm{~mL}$ lactose broth (Difco, USA), and were incubated at $35^{\circ} \mathrm{C}$ for $48 \mathrm{~h}$. Bacterial growth in lactose broth $(10 \mu \mathrm{L})$ was plated on brilliant green bile agar (Difco, USA), and was further incubated at $35^{\circ} \mathrm{C}$ for $24 \mathrm{~h}$. Lactose-positive strains were isolated and maintained in skim milk with $20 \%$ glycerol. For analysis, all strains were cultivated in tryptone broth soy broth at $35^{\circ} \mathrm{C}$ for 24 h. The strains were plated on MacConkey Agar $\left(35^{\circ} \mathrm{C}, 24 \mathrm{~h}\right)$, and lactose-positive colonies were used for identification.

The biochemical profiles of the strains used were confirmed by Vitek2 Gram-negative test cards ${ }^{4}$ (Biomérieux, France) in an automated Vitek ${ }^{\circledR} 2$ instrument. All strains used had phenotypic profiles compatible with that of E. cloacae.

Antimicrobial susceptibility and minimum inhibitory concentrations were assessed in the automated Vitek ${ }^{\circledR} 2$ instrument with AST cards (Biomérieux, France) ${ }^{8}$.

We observed resistance to colistin in a total of $9 / 23$ (39.1\%) isolates - 6/9 (66.7\%) from shrimp and 3/14 (21.4\%) from fish. Minimum inhibitory concentration (MIC) of $\geq 16 \mathrm{mg} / \mathrm{mL}$ was observed in 8 strains ( 5 from shrimp and 3 from fish) and an MIC of $\leq 5 \mathrm{mg} / \mathrm{mL}$ was detected in 15 strains (11 from fish and 4 from shrimp). Thus, our results confirmed the presence of colistin-resistant bacteria in animals from aquaculture. The difference between the contamination indices maybe associated with different culture conditions under which the shrimp and fish were maintained.

In the present study, detection of resistant $E$. cloacae strains maybe indicative of indiscriminate use of drugs in the culture of aquatic organisms, since fish and shrimp, the sources of 
bacteria, were obtained from farms in the State of Ceará, Brazil. Antibiotic use in farm animals has been criticized for contributing to antibiotic resistance 9 .

Recent increases in antimicrobial resistance have been recognized. A relatively novel method for combating multi-drug resistant bacteria is the use of antimicrobial peptides (AMPs), including colistin, which is currently regarded as the last line of antimicrobial therapy ${ }^{10}$.

Pathak and Gopal ${ }^{11}$ also detected mesothermic and heterotrophic aerobic bacteria that are resistant to colistin (98\%) in fish (catfish Clarias batrachus). Resistant bacteria in fish may pose risk to fish fauna and public health. In addition, the presence of colistin-resistant gram-negative bacteria (Vibrio cholerae) in shrimp was reported by Dalsgaard et al. ${ }^{12}$.

In veterinary medicine, colistin has been used for decades to treat and prevent infectious diseases ${ }^{13}$. The administration of antimicrobials in aquaculture provides selective pressures that promote the growth of multiple resistant bacteria in the cultured fish and shrimp ${ }^{14}$.

Our results indicated that enterobacteria resistant to drugs are present in fish and shrimp. These data confirm potential risk to consumer health, and point to the need to establish measures that can control the use of antimicrobials in aquaculture as well as to monitor fish intended for human consumption.

\section{Conflict of interest}

The authors declare that there is no conflict of interest.

\section{Financial support}

The first author received a post graduate scholarship from the Coordenação de Aperfeiçoamento de Pessoal de Nivel Superior.

\section{REFERENCES}

1. Leong LEX, Shaw D, Papanicolas L, Lagana D, Bastian I, Rogers GB. Draft genome sequences of two Enterobacter cloacae subsp. cloacae strains isolated from Australian hematology patients with bacteremia. Genome Announc. 2017;5(3):pii:e00756-17.

2. Moradigaravand D, Reuter S, Martin V, Peacock SJ, Parkhill J. The dissemination of multidrug-resistant Enterobacter cloacae throughout the UK and Ireland. Nat Microbiol. 2016;1:16173.
3. Akoachere JF, Bughe RN, Oben BO, Ndip LM, Ndip RN. Phenotypic characterization of human pathogenic bacteria in fish from the coastal waters of South West Cameroon: public health implications. Rev Environ Health. 2009;24(2):147-56.

4. Harada K, Shimizu T, Mukai Y, Kuwajima K, Sato T, Kajino A, et al. Phenotypic and molecular characterization of antimicrobial resistance in Enterobacter spp. Isolates from companion animals in Japan. PLoSOne. 2017;12(3):e0174178.

5. Lin J, Zhao F, Feng Y, Zong Z. Draft genome sequence of a highlevel colistin-resistant clinical strain of the Enterobactercloacae complex. Genome Announc. 2017;5(14):e00131-17.

6. Chew KL, La MV, Lin RTP, Teo JWP. Colistin and polymyxin B susceptibility testing for carbapenem-resistant and mcrpositive Enterobacteriaceae: comparison of sensititre, microScan, Vitek 2, and etest with broth microdilution. J Clin Microbiol. 2017;55(9):2609-16.

7. Karaaslan A, Çağan E, Kadayifci EK, Atıcı S, Akkoç G, Yakut N, et al. Intravenous colistin use for multidrug-resistant gram-negative infections in pediatric patients. Balkan Med J. 2006;33(6):627-32.

8. Bobenchik AM, Deak E, Hindler JA, Charlton CL, Humphries RM. Performance of Vitek 2 for antimicrobial susceptibility testing of Acinetobacter baumannii, Pseudomonas aeruginosa, and Stenotrophomonas maltophilia with Vitek 2 (2009 FDA) and CLSI M100S 26th edition breakpoints. J Clin Microbiol. 2017;55(2): 450-56.

9. Economou V, Gousia P. Agriculture and food animals as a source of antimicrobial-resistant bacteria. Infect Drug Resist. 2015;8:49-61.

10. Sierra JM, Fusté E, Rabanal F, Vinuesa T, Viñas M. An overview of antimicrobial peptides and the latest advances in their development. Expert Opin Biol Ther. 2017;17(6):663-76.

11. Pathak SP, Gopal K. Occurrence of antibiotic and metal resistance in bacteria from organs of river fish. Environ Res. 2005;98(1):100-3.

12. Dalsgaard A, Mazur J, Dalsgaard I. Misidentification of Vibrio cholerae $\mathrm{O} 155$ isolated from imported shrimp as O serogroup $\mathrm{O} 139$ due to cross-agglutination with commercial O139 antisera. J Food Prot. 2002;65(4):670-72.

13. Catry B, Cavaleri M, Baptiste K, Grave K, Grein K, Holm A, et al. Use of colistin-containing products within the European Union and European Economic Area (EU/EEA): development of resistance in animals and possible impact on human and animal health. Int J Antimicrob Agents 2015;46(3):297-306.

14. Kathleen MM, Samuel L, Felecia C, Reagan EL, Kasing A, Lesley $\mathrm{M}$, et al. Antibiotic Resistance of Diverse Bacteria from Aquaculture in Borneo. Int J Microbiol. 2016;2016:Article 2164761:1-9. 